\title{
BRANDING AS THE BASE OF EUROPEAN FOOTBALL CHAMPIONSHIP COMPETITIONS DEVELOPMENT
}

\author{
Valentin Kutsev
}

\begin{abstract}
Резюме. Брендинг є маркетинговою діяльністю зі створення довгострокової переваги до товару даної фрірми, відношення споживача до торгової марки, рекламних звернень, які виділяють товари серед конкурентів і створюють їх образ. Особливістю бренда UEFA Euro є співпраця з іншими брендами. Ціна і прибутковість бренду Еиго є актуальними і повністю залежать від спонсорів, які беруть участь у змаганнях, а також медіа, що укладають контракти з UEFA.
\end{abstract}

Ключові слова: бренд Euro, бренд UEFA Euro, брендинг, маркетингова діяльність.

\begin{abstract}
Резюме. Брендинг является маркетинговой деятельностью по созданию долгосрочного предпочтения к товару данной фрирмы, отношению потребителя к торговой марке, рекламным обращениям, которые выделяют товары среди конкурентов и создают их образ. Особенностью бренда UEFA EUro является сотрудничество с другими брендами. Цена и доходность бренда Еuго актуальны и полностью зависят от спонсоров, которые принимают участие в соревнованиях, а также медиа, заключающих контракты с UEFA.
\end{abstract}

Ключевые слова: бренд Euro, бренд UEFA Euro, брендинг, маркетинговая деятельность.

Introduction. Branding is the marketing activity on creating the long-term preference to the goods of the given firm; it is consumer's relation to the trademark, packing, the advertising appeals that allocate the goods among competitors and creating its image. The importance of branding is wide spread as in countries with high-developed market, so and for transition economy states. It is connected with rivalship in different spheres of national and global economical relations. Practically all countries that have any human and industrial potential have chosen market relations as the base of their development. For example we can mention CIS countries and China that has brought about $30 \%$ of world's people resources and territory from administrative to market relations.

Analysis of recent. International authors basically describe the problems of branding in club football sphere. They research regularities of club relations in modern, high-developed states (Sue Bridgewater [8], W. Lagae [10], S. Dobson [9]). But the system of brand building of the large global football competitions stays aside from their views. In addition, the special review for brand development in countries with transition economics is needed.

The goal of the research is to justify the regularities of branding usage in countries with transition economics.

Objectives of the research:

1. Summarize the ways of branding usage during global sports events organization.

2. Analyse the common sides and the differences of using brand identities in different spheres of business.
3. Determine the existing problems in branding implementation in different sides of football competitions on global and national levels.

Research methods and organization. Literature analysis, legal documents analysis, the method of expert's opinions, during which were asked the leading specialists of the Ministry of physical education and sports of Ukraine, as well as Ukraine football federation.

The research results and their discussion. The demographic composition of sport consumers has become more complex. Thus, the competition for the spectators has grown tighter, and the necessity for more professional marketing has also increased. Sport clubs have been looking for a better way to attract and retain their fans and customers. Advertising Age invented the term «Sport marketing» in 1979, because at the time marketers used sports more frequently for their benefits. Any casual television viewer can notice the use of sport images and athletes. The use of sports when selling beer, cars and a whole range of other products can be seen constantly on commercials and sports events.

Sport marketing can be considered as a procedure of marketing concepts, which provides sport services and products and the marketing of nonsport products through the help of sport. Therefore, sport marketing has two features. Firstly, there are the methods those general marketing uses to sportrelated products and services. Secondly, there is the marketing through sport for other industrial products or services. Sport marketing seeks to fulfill the needs and wants of consumers, like any other form of marketing. 
Branding starts with a brand, which includes the name, logo, symbols and feelings associated with a sports organization. There is the define of the brand as follows: «distinguishing a name and/or a symbol (such as a logo, trademark, or package design) intended to identify the goods or services of either one seller or a group of sellers, and to differentiate those goods or services from the competitors». A brand signals to the customer the source of a product and protects both the customer and the producer from the competitors who would bring identical products to markets.

The name and marks of a brand are important facets of branding in the field of sports, because when these are associated with a sport organization they provide a point of differentiation from the other sport products that exist in the marketplace. The brand name, logos, marks, and colors of a sport organization serve as a trigger to other feelings and attitudes towards the sport organization. The key point about branding in sport is that it goes much deeper than these facets of an organization. Branding really is about what a customer thinks and feels when he/she sees the marks of a particular brand.

The benefits of consuming sports are much more experiential that tangible. You cannot touch or taste the actual baseball game, but you can taste the toothpaste you put into your mouth. The emotion tied to sport makes the experience of consuming the sport so unique. Sport has the ability to trigger emotions of consumer in a way, which any other leisure or entertainment products has not. Sports have the possibility to create experiences and emotions. That gives an advantage to sport organizations.

Brand equity comprises the brand knowledge, brand loyalty and brand associations. This increases or decreases the value provided by a product or service. Brand management begins with building up a brand identity and this indicates what the brand stands for and promises to customers. There are generally 8 to 12 elements that represent concepts such as product scope, product attributes, quality/values, uses, users, and country of origin, organizational attributes, brand personality, and symbols. The most important of these are the core identity elements and extended identity elements. Additionally the brand essences and the brand identity can communicate with each other.

The brand loyalty of the customer base is often the core of brand's equity. If customers don't care about the brand and in fact buy products by the price or the feature of the product with no concern of the brand name, there is likely little equity on the brand. But if customers continuously buy products of the same brand despite the price or feature, substantial value exist in the brand. If the brand has the loyalty of customers it reduces the chances of the customer switching to another brand even if the brand makes changes on the price or feature. Brand loyalty is one indicator of brand equity that is probably linked to future profits, since brand loyalty directly translates into future sales. There are different levels of loyalty. Each level represents different challenges in marketing and different type of asset to manage and exploit.

In sport business brand loyalty is not only about products or services. Customer's brand or in this case fan attach to a sport team by feelings. When a team is able to generate a wealth of assets linked to its brand, the team is thought to have high brand equity. The loyalty to the team brand increases when brand equity of the brand is high. If brand loyalty of the sport team is high the sport marketer can expect increases in revenue through ticket and merchandise sales. When brand loyalty is high it also results in higher viewing audience for the events, which allows the sport organization to gain higher broadcast profit for the rights to televise their events. By gaining more television visibility the organization can attract more sponsors looking to spread their brand to a higher audience.

Brand loyalty in sport is different than in other businesses. In sport customers watch their favorite team because they are emotionally attached to the club. These customers are called in this case fans and they are the fans of the club for different reasons, for example the club is from their hometown or it might have strong history and are doing well in the league. In football there is a belief that fans will go to see their team no matter if it rained or not. But this is not entirely true, because according to Dr. Alan Tapp there are different levels of loyalty. There are fans that simply love the game, football lovers and at the bottom of the rank there are carefree casuals. The real fanatics will go to every game of their team and know everything of their club. The repertoire fans will go to enjoy football as a sport and the casual carefree will support from afar, just waiting for the results. In marketing way of thinking this is something that should be considered and fans should not be taken for granted in any way.

When a fan becomes loyal to a team he/she usually remains as a fan for only that specific team. That means he will buy only products of that particular organization. It means revenue for the organization and at the same time profit lost for another one. That is why big club, especially worldwide brands, keeps competing for fans and potential customers.

People who are emotionally attached to a team have higher propensity to pur- chase a team product and evaluate them positively. Team loyalty, also defined as enduring allegiance to a particular team, was the most important factor in determining 
spectators desires to attend sport events. «Even tough there are many behaviors that may be an expression of fan loyalty before research has relied heavily on attendance data to measure fan loyalty to sport teams».

There are some concepts connected with brand, which experts operate. Each brand has certain attributes (Brand Attributes) - the functional or emotional associations, the buyers and potential clients appropriated to a brand. Attributes of a brand can be both positive, and negative, can have various strength and importance for different segments of the market. Any brand possesses the main, basic characteristic, which defines its essence (Brand Essence). All attributes of a brand in aggregate make individuality of a brand (Brand Identity), which is created and supported by brand expert. Individuality of a brand expresses what should brand mean and is the certain long-term promise to consumers from authors of a brand.

At each concrete moment every brand has certain image (Brand Image) - a unique set of associations, which are in consumer's mind at the moment. These associations express that brand means right now, and are the momentary promise to consumers from authors of a brand. In particular, the advertising campaign can generate image of a brand. It is important to notice, that image of a brand is that what is in consumers' minds at the moment, while individuality of a brand is much more long-term concept.

In practice often you meet two close concepts a brand and the trademark. Actually the brand is not only the trademark consisting of the name, a graphic presentation (logo) and sound symbols of the company or the goods. Concept of a brand is wider as it has such aspects in addition:

- the good or service with all its characteristics;

- a set of characteristics, expectations, and the associations perceived by the user and attributed to the goods (brand-image);

- the information about the consumer;

- the promises of any advantages given by the author of a brand to consumers, that sense which is put in it by founders (widespread enough error consists that founders of a brand believe that their perception and perception of target audience are identical; in practice often enough it differs from perception of the consumer).

In 2012 Ukraine carried out the final tournament of the European football championship, the main competition of the national teams held under the guidance of UEFA. Since 1960, tournament passes between the World championships. It is possible to consider this year the beginning of the Championship brand development, which at present is the third on popularity sports action in the world.
Originally tournament was called the European nations Cup, and in 1968 the name have replaced with the European football championship. Until 1980 only 4 teams took part in a final part of tournament, 1980-1996 - 8 national teams, 19962016 - 16 national teams, and since 201624 teams for the first time will take part in a final part of the championship. In the given tendency development of quality of competition, its commercial appeal and popularity among various levels of population is seen. As consequence, the European championship became elite competition, a brand that is one of the most popular in the world.

And the specialty of the UEFA Euro brand is its cooperation with other brands. The price and profitability of Euro brand is actual only if sponsors take part in the competitions, if Medias sing the contracts. This is the situation from one side. And from the other, sponsors and Medias use Euro for their own brand building, for interaction with the consumers through football, and as a result for getting profit from tournament.

Today countries show their interest for carrying out large sports actions in their countries, as much as possible using them for development of the image, a brand of the country.

South Africa Republic that carried out the world football championship actively used the fact of the tournament during last three years before competition. The main objectives, which have been put by this country: attraction of investments into infrastructure development, attraction of tourists. Southern Africa has created the favorable environment for development of private and state partnership in which frameworks the countrybranding program has been realized. The culmination of this program was carrying out of the world football championship.

Similar work was done also by Germany, which organized the World football championship on 2006. «Germany - the country of ideas», this was the main slogan of the 2006 World football championship. The overall objective of the Germany state national branding campaign consisted in showing, that «Germany is the country of ideas», and to prove to the world, that the country is competitive, innovative, with spirit of production.

Today the international community interest to Ukraine is low enough, for many people it is difficult to find the country on a world card. At the same time Euro-2012 from the point of view of PR was the international information occasion that helped to correct this situation and improve the Ukraine's reputation.

Conclusions. The European football championship is over billion the people attracted which attention was chained to our state during viewing of matches. 
It is hundred thousand spectators who were on stadiums, and millions foreigners who enjoyed advantages of the fan zones. The companies did a lot of marketing activities for their own development in the Euro-2012 context.

Concerning an internal audience (for the companies it is own employees, the inhabitant of areas, small towns or the bridge where they do business, their partners and suppliers), the Euro-2012 was a good occasion for qualitative internal mobilization of Ukrainians. As well as business, Ukraine requires owners who are capable to lead own economy to an order and to be ready to show hospitality and it is to use Championship carrying out favorably.

In the conditions of modern development of market economy the branding is one of the basic mechanisms of business development and gaining loyalty of wide ranges of clients. The European football championship today is the large businessproject, which client audience coverage is the population of practically the whole world.

\section{References}

1. Michuda Y. Professional sport as a kind of entrepreneurship / Y. Michuda // Theory and methods of phys. education and sport. - 2005. - №1. - P. 30-35.

2. Tomich M. Marketing in sport. Market and sports goods / M. Tomich. - Moscow, 2003. - 224 p.

3. Yavlenin I. Sports marketing: [http://www.marketing.spb.ru/lib-special/branch/sport.htm]

4. J. Amis. Cornwell. Global Sport Sponsorship (Sport Commerce and Culture) / Amis J., T. Cornwell. - Oxford, 2005. -256 p.

5. J. Mullin. Sport marketing / Mullin J. - Champaign, US, 2007. - 539 p.

6. L. Masteralexis. - Principles and Practice of Sport Management / Masteralexis L., Barr C., Hums M. Sudbury, 2012. $-616 \mathrm{p}$.

7. M. Pritchard Leveraging Brands in Sport Business / Pritchard M., Stinson J. - Routledge, 2013. - 262 p.

8. S. Bridgewater. Football Brands / Bridgewater S. - London, 2010. - 256 p.

9. S. Dobson. The Economics of Football / Dobson S., Goddard J. - Cambridge, 2011. - 474 p.

10. W. Lagae. Sports Sponsorship and Marketing Communications: A European Perspective / Lagae W. London, 2005. - 248 p. 